\title{
Fruit and seeds biometry and germination of Psidium cauliflorum Landrum \& Sobral
}

\section{Biometria de frutos e sementes e germinação de Psidium cauliflorum Landrum \& Sobral}

\author{
Lorena da Paz OLIVEIRA'; Andrea Vita Reis MENDONÇA'; Geisislaine do Carmo Reis ARAÚJO'; \\ Taise Almeida CONCEIÇÃO'; Manuela Oliveira de SOUZA²
}

${ }^{1}$ Center of Agricultural, Biological and Environmental Sciences (CCAAB), Reference Center on Forest Restoration of the Atlantic Forest Biome -CRRF/MA, Universidade Federal do Recôncavo da Bahia (UFRB), Brazil.

${ }^{2}$ Center of Exact and Technological Science (CETEC), Reference Center on Forest Restoration of the Atlantic Forest Biome CRRF/MA, Universidade Federal do Recôncavo da Bahia (UFRB), Brazil +Correspondence: manuelasouza@ufrb.edu.br

\section{Recebido em: 25-02-2018; Aceito em: 22-10-2018}

\begin{abstract}
The biometric characterization of fruits and seeds, obtaining optimum temperatures and photoperiods for germination and the definition of numbers and counting intervals in the germination tests of Psidium cauliflorum were the objectives of this work. Fruits were obtained from four matrices located in the Environmental Protection Area of Lago de Pedra do Cavalo, in São Gonçalo dos Campos-BA. The following temperatures were tested: $25^{\circ} \mathrm{C}$; $30{ }^{\circ} \mathrm{C}$; and $25-30^{\circ} \mathrm{C}$, in addition to three light conditions: absence of light; $8 \mathrm{~h}$ photoperiod; and $12 \mathrm{~h}$ photoperiod. One kilogram of fruit contains about 260 fruits and 1.344 seeds. Germination performance was higher at the alternating temperatures of $25-30^{\circ} \mathrm{C}$, in the presence of light ( $8 \mathrm{~h}$ photoperiod). The germination test lasted 77 days, with the first count at 21 days and subsequent counts at 15 day-intervals.
\end{abstract}

Additional keywords: Atlantic forest; forest species; temperature.

\section{Resumo}

A caracterização biométrica de frutos e sementes, a obtenção de temperaturas e fotoperíodos ótimos para a germinação e a definição dos números e intervalos de contagens nos testes de germinação de $P$ sidium. cauliflorum foram os objetivos deste trabalho. Os frutos foram obtidos de quatro matrizes, localizadas na Área de Proteção Ambiental do Lago de Pedra do Cavalo, em São Gonçalo dos Campos-BA. Foram testadas as temperaturas de $25^{\circ} \mathrm{C} ; 30^{\circ} \mathrm{C}$ e $25-30^{\circ} \mathrm{C}$ e três condições de luz: ausência de luz, fotoperíodos de $8 \mathrm{~h}$ e de $12 \mathrm{~h}$. Um quilograma de fruto contém cerca de 260 frutos e 1.344 sementes. O desempenho germinativo foi superior nas temperaturas alternadas de $25-30^{\circ} \mathrm{C}$, na presença de luz e fotoperíodo de $8 \mathrm{~h}$. $\mathrm{O}$ teste de germinação teve duração de 77 dias, com a primeira contagem aos 21 dias e mais quatro contagens a intervalos de 15 dias.

Palavras-chave adicionais: espécie florestal; Mata Atlântica; temperatura.

\section{Introduction}

The growing need for forest conservation and recovery of degraded areas generates an increased demand for seeds and seedlings of native forest species (Melo et al., 2011). Thus, it is fundamental to develop methodologies that may contribute to the field of seed technology, especially in the forest sector, where there is a lack of studies regarding the high species richness.

For the field of forestry, the search for information on fruit and seed production and germination protocols is of paramount importance. In this sense, for the commercialization of seeds, Law 10.711 (Brasil, 2003) and Decree No. 5,153 of July 23, 2004 (Brasil, 2004) demand the characterization of seed lots of interest, requiring the application of germination tests. The conditions for carrying out these tests, such as temperature and photoperiod are species-specific. Despite the great effort of researchers and the Ministry of Agriculture to standardize the ideal conditions for the propagation of native plants, as can be seen in the Rules for Analysis of Forest Seeds (Brasil, 2013), there is still a lack of information for many species, such as Psidium cauliflorum (Landrum \& Sobral, 2006).

$P$. cauliflorum Landrum \& Sobral is a tree species of the family Myrtaceae, found in the Atlantic forest, with confirmed occurrence in the states of Bahia, Espírito Santo and Rio de Janeiro (Sobral et al., 2015). The knowledge about the biology, ecology, forestry and potential use of the species is practically nonexistent. However, there is preliminary information on the chromatographic profile of essential oils, comprising different biological functions that occur in the species (Bernardes, 2017).

The present study evaluates fruit and seed biometry, optimum temperatures and photoperiods for germination and determines counting numbers and counting intervals in the germination tests of P. cauliflorum. 


\section{Materials and methods}

Characterization of the production area of the plant material

Psidium cauliflorum fruits were collected from four matrices, the distance between them being 48 to $97 \mathrm{~m}$ (Table 1). Collection was carried out in the Environmental Protection Area of Lago de Pedra do Cavalo in the municipality of São Gonçalo dos Campos, Bahia State.The collection was based on the floristic survey carried out by Souza et al. (2018). The total area of the EPA comprises 30,156 hectares around Lago de Pedra do Cavalo, between

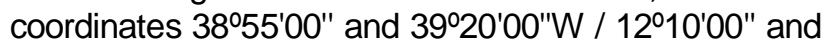
$12^{\circ} 40^{\prime} 00^{\prime \prime S}$. According to the classification proposed by Alvares et al. (2013), the climate of the region is tropical with dry summer (As), with annual average temperature of 24 to $26^{\circ} \mathrm{C}$ and annual rainfall of 700 to $1000 \mathrm{~mm}$.

Table 1 - Location and characterization of matrices from seeds Psidium. cauliflorum Landrum \& Sobral

\begin{tabular}{cccccc}
\hline Matriz & $\begin{array}{c}\text { Latitude } \\
\text { (South) }\end{array}$ & Longitude (West) & Altitude $(\mathrm{m})$ & Number of fruits collected Date of fruit collection \\
\hline 1 & $12^{\circ} 19^{\prime} 55.956^{\prime \prime}$ & $38^{\circ} 58^{\prime} 41.692^{\prime \prime}$ & 59 & 441 & $10 / 10 / 2015$ \\
2 & $12^{\circ} 19^{\prime} 55.370^{\prime \prime}$ & $38^{\circ} 58^{\prime} 36.460^{\prime \prime}$ & 197 & 200 & $10 / 17 / 2015$ \\
3 & $12^{\circ} 19^{\prime} 53.286^{\prime \prime}$ & $38^{\circ} 58^{\prime} 35.633^{\prime \prime}$ & 111 & 350 & $11 / 16 / 2015$ \\
4 & $12^{\circ} 19^{\prime} 53.156^{\prime \prime}$ & $38^{\circ} 58^{\prime} 35.831^{\prime \prime}$ & 110 & 509 & $11 / 18 / 2015$ \\
\hline
\end{tabular}

\section{Characterization of fruits and seeds}

All experimental activities were developed in the laboratory of Dendrology and Forest Ecology of the Federal University of Reconcavo da Bahia, Cruz das Almas Campus -BA. After harvesting, the fruits were benefited and separated into samples of 100 units for each matrix for biometric characterization and fresh mass determination. A sample of 100 fruits was randomly selected for seed counting and diameter measurement with a $0.01 \mathrm{~mm}$ precision digital caliper. The measurement was performed in two positions for each fruit, obtaining the average diameter and the circularity index. The circularity index $(\mathrm{Cl})$ was obtained according to Guedes et al. (2011): $\mathrm{Cl}=(\mathrm{a} / \mathrm{b}) \times 100$, wherein: $\mathrm{a}=$ diameter of the largest axis; and $\mathrm{b}=$ diameter of the smallest axis.

To determine 1000 seed weight were used 41 samples of 100 seeds (12 samples from matrix $1 ; 6$ from matrix 2; 9 from matrix 3 and 14 from matrix 4). Water content was determined in an oven at $105^{\circ} \mathrm{C} \pm$ $\pm 3^{\circ} \mathrm{C}$ (Brasil, 2009).

Four samples of 100 seeds, one from each matrix, were randomly selected for length and diameter measurement in two positions. With these data, the approximate value of the degree of sphericity $(\varphi)$,and the seed area $(A)$ and volume $(V)$ were obtained according to Guedes et al. (2011).

\section{Temperatures and photoperiods for the germina- tion test}

Germination tests were carried out separately for each of the four matrices, since there was variation in the date of fruit and seed collection. As soon as fruits were located and collected in the field, they were benefited and measured, with subsequent application of the germination tests.

The experiment of matrix 1 was conducted in a completely randomized design (CRD), in a $3 \times 3$ factorial scheme, testing three temperatures $\left(25^{\circ} \mathrm{C}, 30^{\circ} \mathrm{C}\right.$ and $\left.25-30^{\circ} \mathrm{C}\right)$ and three light conditions $(0 \mathrm{~h}, 8 \mathrm{~h}$ and $12 \mathrm{~h}$ ) with four replicates of 25 seeds. For the $25-30{ }^{\circ} \mathrm{C}$ condition, the temperature of $30{ }^{\circ} \mathrm{C}$ corresponded to the hours with light and the temperature of $25^{\circ} \mathrm{C}$ to the hours in the absence of light. In the condition of total absence of light $(0 \mathrm{~h})$, the temperatures of $25^{\circ} \mathrm{C}$ and $30{ }^{\circ} \mathrm{C}$ were used for 12 hours each. The seeds were placed in germitest ${ }^{\circledR}$ paper rolls moistened with distilled water at a ratio of 2.5 times the weight of dry paper (Brasil, 2009). The rolls were placed in transparent plastic bags and deposited in germination chambers. For the treatments with absence of light, the paper rolls, individualized in plastic bags were deposited in envelopes made with black cardboard paper, avoiding incidence of light in the seeds.

Daily observations were made, counting the number of germinated seeds (primary root emission) and normal seedlings. At the end of the germination test, abnormal seedlings and hard and dead seeds were also counted. For the treatments with absence of light, evaluations were carried out only in the last count.

Experiments on matrices 2, 3, and 4 were conducted under the same experimental conditions as those performed on matrix 1 , excluding the treatment with absence of light and the counts performed every seven days.

\section{Comparisons between seeds lots}

Comparisons were made between the four matrices regarding the germination test variables and based on the treatments. The temperature and photoperiod of best performance were evaluated for each matrix, with four replicates. Regarding the variables of fruit and seed characterization (number of seeds per 100 fruits, average fruit diameter, seed width, 1000 seed weight and seed length), six replicates per matrix were used. 


\section{Evaluated variables}

The variables evaluated in all experiments were percentage of normal seedlings (\%NS); shoot length $(S L)$, main root length (MRL), and total root length (TRL), based on the number of normal seedlings; shoot length (SL 25), main root length (MRL 25) and total root length (TRL 25), based on the initial number of seeds and according to Guedes et al. (2009); germination rate (GR) and seedling emergence rate (Maguire, 1962), germination time (GT) and seedling emergence time (SET, considering normal seedlings) (Borghetti \& Ferreira, 2004); and period of start germination and seedling growth.

Seedling emergence rate (SER) and seedling emergence time (MSET) refer to an adaptation of the germination rate and mean germination time, since they were obtained from normal seedling emergence.

\section{Statistical analysis}

For data analysis related to fruit and seed biometry, descriptive analysis and estimation by confidence intervals $(\alpha=0.05)$ were used.

Moreover, analysis of variance and multiple mean comparison tests were used in the data analysis. For the variables the beginning of germination and seedling growth, as well as for comparison between seed lots, the non-parametric Kruskal-Wallis test was used. Data were analyzed using Program $R$ version 3.1.3 (R Development Core Team, 2014).

\section{Results and discussion}

\section{Characterization of fruits and seeds}

Based on the obtained data, one kilogram of Psidium cauliflorum fruit contains about 255 fruits and 1.344 seeds, which corresponds to approximately $86.10 \mathrm{~g}$ seeds, the average thousand seed weight being $65.6 \mathrm{~g}$. The mean water content in seeds from matrices 1, 2, 3, and 4 was 23.38; 12.44; 1.24; and $18.29 \%$, respectively. Information related to seed/fruit $\mathrm{kg}$ is of practical importance to the silviculture of the species, since the quantity of fruit to be collected to meet the demand of seedling production can be estimated minimizing seed waste, thus contributing for the sustainable use of this resource. Excessive collection of fruits and seeds in a natural environment may lead to a decrease in the availability of this resource to dispersing agents, reducing the chances of natural propagation of the species.

Fruits are approximately circular (Figure 1a), with a mean diameter around $16.68 \mathrm{~mm} \pm 0.31 \mathrm{~mm}$ $(\alpha=0.05)$, and a circularity index between 80.9 and $100 \%$. Seed shape varies from circular to elliptical (Figure 1b), with maximum sphericity of 98.68 and minimum of 70.26. The average seed area was $0.95 \pm$ $0.061 \mathrm{~cm}^{2}$, and the average seed volume was $0.063 \pm$ $0.007 \mathrm{~cm}^{3}(\alpha=0.05)$.

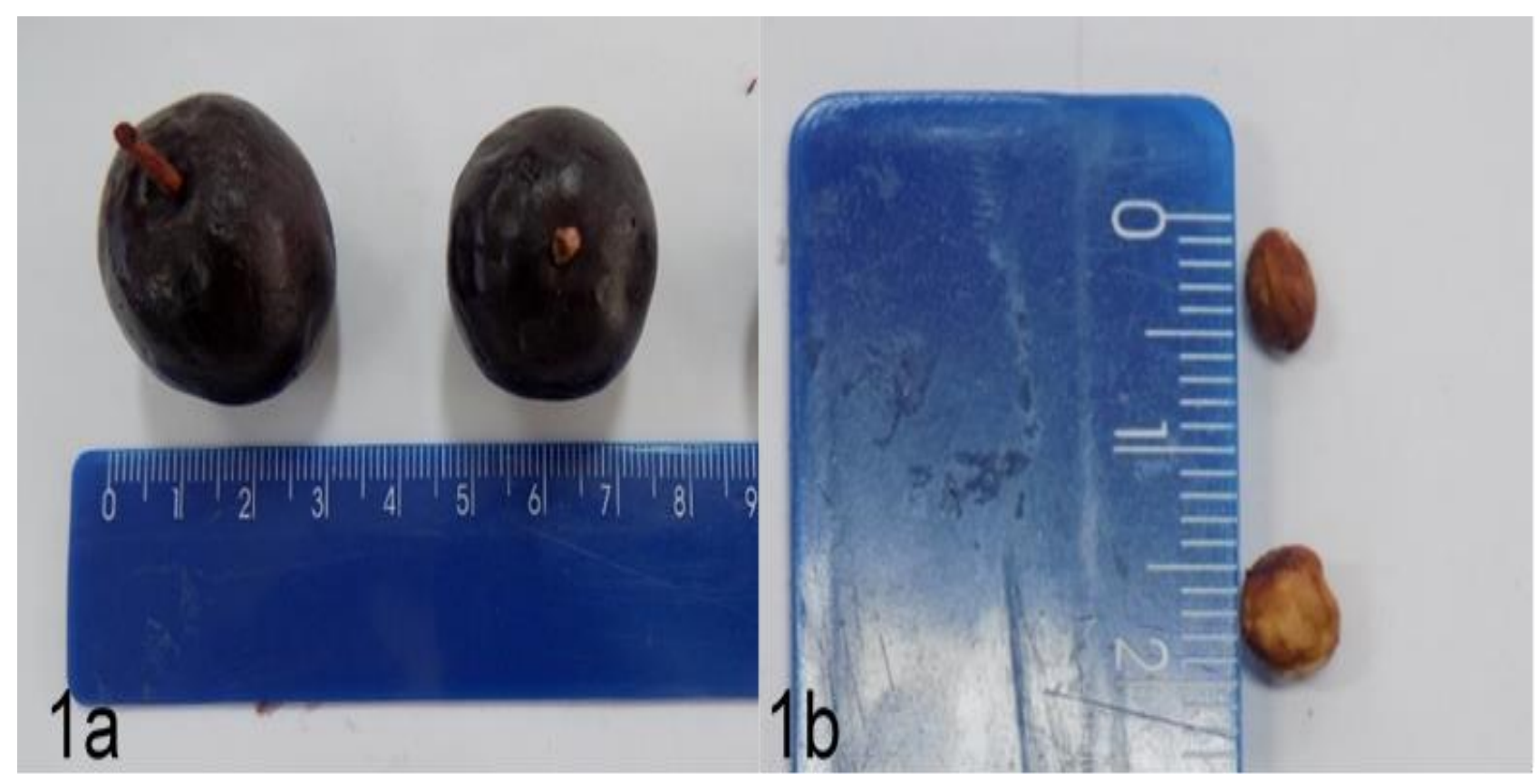

Figure 1. Fruits (a) and seeds (b) of Psidium cauliflorum Landrum \& Sobral.

To evaluate the distribution of the number of seeds per fruit, lots composition was calculated in the four matrices (100 seeds per matrix); of the 400 evaluated seeds, the number of seeds per fruit ranged from 1 to 28 . However, $65.5 \%$ of the fruits showed one to four seeds (Figure 2). 


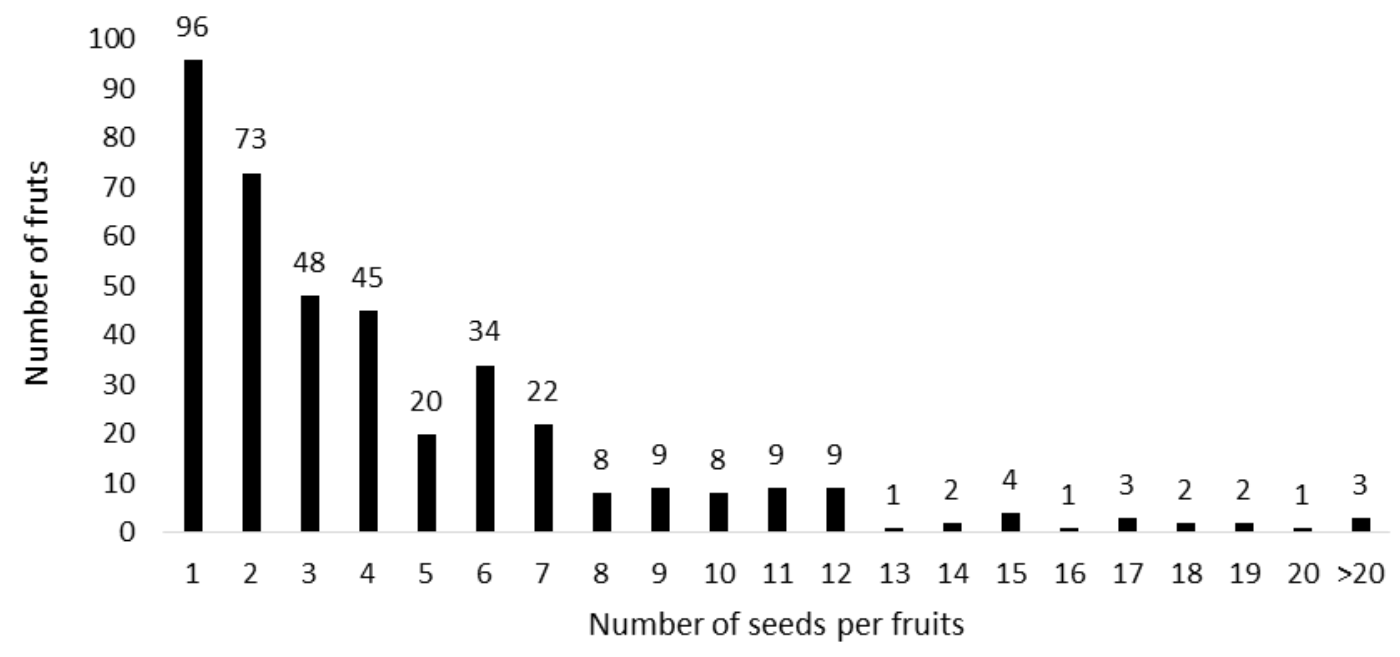

Figure 2. Distribution of number of seeds per fruit of Psidium cauliflorum Landrum \& Sobral.

\section{Temperatures and photoperiods for the germination test}

Light and temperature acted independently on the germination of seeds from matrix 1. The temperatures of $25^{\circ} \mathrm{C}$ and $25-30^{\circ} \mathrm{C}$ provided similar performance for most of the evaluated variables, except for mean germination time, which was lower for the alternating temperature of $25-30^{\circ} \mathrm{C}$ (Table 2$)$.
At $30^{\circ} \mathrm{C}$, there was no germination.

Photoperiods of $8 \mathrm{~h}(77.5 \%)$ and $12 \mathrm{~h}(72 \%)$ were equally efficient for normal seedling emergence (Table 2). The absence of light did not favor the percentage of normal seedlings. These results are according to those found by Araújo Neto et al. (2013) when studying Acacia polyphylla DC. and Silva et al. (2008) with Mimosa caesalpiniifolia Benth.

Table 2 - Percentage of normal seedlings formation (\% NSF), shoot length (SL) and root length (RL) in relation to the number of normal seedlings formed, shoot length $(S L 25)$ and root length $(R L 25)$ in relation to the initial number of total seeds, germination speed index (GSI), normal seedlings formation speed index (NSFSI), mean germination time (GT) and for formation normal seedlings (NSFT) to seeds from matrix 1 of Psidium cauliflorum Landrum \& Sobral.

\begin{tabular}{lccccccccc}
\hline Causes of variation & NSF & SL & SL 25 & RL & RS 25 & GSI & NSFSI & GT & NSFT \\
\hline Photoperiod & & & & & & & & & \\
$12 \mathrm{~h}$ & $72.0 \mathrm{a}$ & $1.5 \mathrm{c}$ & $0.31 \mathrm{c}$ & $1.7 \mathrm{~b}$ & $0.07 \mathrm{~b}$ & $0.57 \mathrm{a}$ & $0.35 \mathrm{a}$ & $43.5 \mathrm{a}$ & $54.5 \mathrm{a}$ \\
$8 \mathrm{~h}$ & $77.5 \mathrm{a}$ & $1.7 \mathrm{~b}$ & $0.34 \mathrm{~b}$ & $2.2 \mathrm{a}$ & $0.09 \mathrm{a}$ & $0.61 \mathrm{a}$ & $0.40 \mathrm{a}$ & $34.4 \mathrm{~b}$ & $48.6 \mathrm{~b}$ \\
Light absence & $35.5 \mathrm{~b}$ & $1.9 \mathrm{a}$ & $0.39 \mathrm{a}$ & $1.1 \mathrm{c}$ & $0.04 \mathrm{c}$ & - & - & - & - \\
\hline $\mathrm{F}$ & 18.61 & 53.56 & 53.31 & 23.41 & 24.92 & 0.82 & 2.99 & 20.10 & 24.23 \\
$\mathrm{p}$ & 0.00 & 0.00 & 0.00 & 0.00 & 0.00 & 0.40 & 0.10 & 0.00 & 0.00 \\
$\mathrm{CV} \%$ & 24.27 & 4.52 & 4.52 & 18.99 & 18.99 & 15.21 & 14.45 & 10.37 & 4.67 \\
\hline Temperature & & & & & & & & & \\
$25^{\circ} \mathrm{C}$ & $61.3 \mathrm{a}$ & $1.70 \mathrm{a}$ & $0.34 \mathrm{a}$ & $1.59 \mathrm{a}$ & $0.06 \mathrm{a}$ & $0.57 \mathrm{a}$ & $0.36 \mathrm{a}$ & $44.8 \mathrm{a}$ & $56.1 \mathrm{a}$ \\
$25-30^{\circ} \mathrm{C}$ & $62.0 \mathrm{a}$ & $1.73 \mathrm{a}$ & $0.35 \mathrm{a}$ & $1.78 \mathrm{a}$ & $0.07 \mathrm{a}$ & $0.61 \mathrm{a}$ & $0.39 \mathrm{a}$ & $33.0 \mathrm{~b}$ & $47.1 \mathrm{~b}$ \\
\hline $\mathrm{F}$ & 0.01 & 1.02 & 0.99 & 2.12 & 2.59 & 0.64 & 1.69 & 34.10 & 55.11 \\
$\mathrm{p}$ & 0.91 & 0.33 & 0.33 & 0.16 & 0.12 & 0.43 & 0.21 & 0.00 & 0.00 \\
$\mathrm{CV} \%$ & 24.27 & 4.52 & 4.52 & 18.99 & 18.99 & 15.21 & 14.45 & 10.37 & 4.67 \\
\hline
\end{tabular}

Means followed for the same letters in the columns do not differ statistically by the Scott-Knott test and $\mathrm{F}$ test at $5 \%$ probability (p), for photoperiod and temperature, respectively. Square root transformation performed for: SL, SL25 and RL25.

Beyond to the lower normal seedling emergence, in the absence of light, the seeds gave rise to albino seedlings and etiolated hypocotyls, which were considered undesirable (Brasil, 2009; Brasil, 2013).
Regarding the influence of light on the germination of $P$. cauliflorum seeds, both the presence and absence of light led to primary root protrusion, characterizing these seeds as neutral photoblastic or non-photoblastic. This result agrees with that observed 
for other forest species such as Heliocarpus popayanensis L. (Brancalion et al., 2008); Dalbergia cearensis Ducke (Nogueira et al., 2014); Caesalpinia leiostachya (Benth.) Ducke (Biruel et al., 2007) and Cochlospermum vitifolium (Will.) Sprengel. (Pereira et al., 2013), evaluated under conditions similar to those of the present work.

The absence of light led to etiolation, agreeing with that observed for J. curcas (Silva et al., 2016). Moreover, there was lower root growth as a result of the respiration process and the plant energy spent in the search for light (Silva et al., 2016). Photoperiod of $8 \mathrm{~h}$ was the condition that most favored root growth, besides providing the shortest mean germination time (Table 2).

According to the Kruskal-Wallis test (chisquare $=5.3$ and $p$-value $=0.15$ ), the beginning of germination of seeds from matrix 1 , characterized by primary root protrusion was not influenced by temperature and photoperiod. The germination of these seeds started between 19 and 28 days, starting at 20 days in most of the sample units. Normal seedling emergence started at 39 days for the temperature of $25^{\circ} \mathrm{C}$ and at 38 days for the alternating temperature of $25-30{ }^{\circ} \mathrm{C}$, regardless of photoperiod. Maximum seedling emergence occurred between 53 and 63 days at $25^{\circ} \mathrm{C}$ and between 38 and 50 days at the alternating temperature of $25-30{ }^{\circ} \mathrm{C}$ (KruskalWallis, chi-square $=11.3$ and $p$-value $=0.0099$ ) .

The last count of this experiment was performed at 70 days for seeds from matrix 1 . However, it was observed that although germination stabilized for most of the sample units before 70 days, seeds were still germinating in this period, although without confirmation of normal seedling emergence. It is recommended, therefore, that in germination tests of $P$. cauliflorum the last count be performed at 77 days.

Regarding matrix 2, temperature and photoperiod worked together for the variables percentage of normal seedlings and normal seedling emergence rate. For germination rate, mean germination time, shoot and root length, and average shoot and root length based on the initial number of seeds, the factors acted independently.

The alternating temperature of $25-30{ }^{\circ} \mathrm{C}$ and photoperiod of $12 \mathrm{~h}$ provided better results for the percentage of normal seedlings (58\%) and normal seedling emergence rate $(0.28)$. At $25^{\circ} \mathrm{C}$, in turn, the two photoperiods tested showed similar results for these variables (Table 3). At $30{ }^{\circ} \mathrm{C}$, germination was zero.

Table 3 - Percentage of normal seedlings formation (\% PN) and normal seedlings formation speed index (NSFSI) of seeds from matrix 2 of Psidium cauliflorum Landrum \& Sobral.

\begin{tabular}{|c|c|c|c|c|}
\hline \multirow{3}{*}{$\begin{array}{l}\text { Treatments } \\
\text { Temperature }\end{array}$} & \multicolumn{4}{|c|}{ Photoperiod } \\
\hline & \multicolumn{2}{|c|}{$\% \mathrm{PN}$} & \multicolumn{2}{|c|}{ NSFSI } \\
\hline & $12 \mathrm{~h}$ & $8 \mathrm{~h}$ & $12 \mathrm{~h}$ & $8 \mathrm{~h}$ \\
\hline $25^{\circ} \mathrm{C}$ & $17.0 \mathrm{bA}$ & $23.0 \mathrm{aA}$ & $0.08 \mathrm{bA}$ & $0.10 \mathrm{aA}$ \\
\hline $25-30^{\circ} \mathrm{C}$ & $58.0 \mathrm{aA}$ & $37.0 \mathrm{aB}$ & $0.28 \mathrm{aA}$ & $0.17 \mathrm{aB}$ \\
\hline $\mathrm{F}$ & \multicolumn{2}{|c|}{5.74} & \multicolumn{2}{|c|}{5.36} \\
\hline $\mathrm{p}$ & \multicolumn{2}{|c|}{0.03} & \multicolumn{2}{|c|}{0.04} \\
\hline CV\% & \multicolumn{2}{|c|}{33.39} & \multicolumn{2}{|c|}{35.67} \\
\hline
\end{tabular}

Means in the lines followed by uppercase letters and in the columns by lower case letters do not differ statistically at $5 \%$ probability by the $\mathrm{F}$ test.

For matrix 2, the alternating temperature of 25$30{ }^{\circ} \mathrm{C}$ yielded higher values of germination rate $(0.39)$ and mean germination time (42.9 days) than the temperature of $25{ }^{\circ} \mathrm{C}(\mathrm{GR}=0.25$ and $\mathrm{MGT}=53.8$ days).

The beginning of germination (Kruskal-Wallis, chi-square $=6.0$ and $p$-value $=0.11$ ) ranged between 21 and 41 days, and normal seedling emergence (Kruskal-Wallis, chi-square $=7.3$ and $p$-value $=0.06$ ) ranged between 34 and 62 days, with higher occurrence at 48 days, without effect of treatments for matrix 2. Maximum seedling emergence also did not differ between treatments with higher occurrence at 55 days.

Temperature and photoperiod acted independently for all the variables studied in matrix 3 . The alternating temperature of $25-30{ }^{\circ} \mathrm{C}$ provided the best results for the percentage of normal seedlings $(28.0 \%)$, germination rate $(0.15)$ and mean germination time (49.8 days). At $30{ }^{\circ} \mathrm{C}$ germination was zero. Photoperiod influenced only the mean germination time, with highlight for the $8 \mathrm{~h}$ photoperiod (Table 4).

The beginning of germination occurred between 21 and 62 days (Kruskal-Wallis, chi-square = 5.9 and $p$-value $=0.053$ ). Normal seedling emergence started between 41 and 61 days, with higher occurrence at 48 days (Kruskal -Wallis, chi-square = 0.42 and $p$-value $=0.081$ ), not varying among treatments.

For matrix 4, temperature and photoperiod acted independently for the percentage of normal seedlings. There was no effect of photoperiod for normal seedling emergence rate, germination rate, mean seedling emergence time, root length, and average root length based on the initial number of seeds. There was effect of temperature on normal seedlings formation, germination speed index and normal seedlings formation speed index (Table 5). 
Table 4 - Percentage normal seedlings formation (\% NSF), germination speed index (GSI), mean germination time (GT) and root length (RL) of seeds from matrix 3 of Psidium cauliflorum Landrum \& Sobral.

\begin{tabular}{lcccc}
\hline Causes of variation & \% NSF & GSI & GT & $\mathrm{RL}$ \\
\hline Photoperiod & & & & \\
$12 \mathrm{~h}$ & $23.0 \mathrm{a}$ & $0.11 \mathrm{a}$ & $56.0 \mathrm{~b}$ & $0.95 \mathrm{a}$ \\
$8 \mathrm{~h}$ & $22.0 \mathrm{a}$ & $0.12 \mathrm{a}$ & $50.3 \mathrm{a}$ & $0.93 \mathrm{a}$ \\
$\mathrm{F}$ & 0.07 & 0.38 & 19.23 & 0.002 \\
$\mathrm{p}$ & 0.80 & 0.55 & 0.00 & 0.96 \\
$\mathrm{CV} \%$ & 34.43 & 36.66 & 4.96 & 12.32 \\
Temperature & & & & \\
$25^{\circ} \mathrm{C}$ & $17.0 \mathrm{~b}$ & $0.08 \mathrm{~b}$ & $56.6 \mathrm{a}$ & $0.97 \mathrm{a}$ \\
$25-30^{\circ} \mathrm{C}$ & $28.0 \mathrm{a}$ & $0.15 \mathrm{a}$ & $49.8 \mathrm{~b}$ & $0.93 \mathrm{a}$ \\
$\mathrm{F}$ & 8.07 & 12.78 & 26.60 & 0.32 \\
$\mathrm{p}$ & 0.02 & 0.00 & 0.00 & 0.58 \\
$\mathrm{CV} \%$ & 34.43 & 36.66 & 4.96 & 12.32 \\
\hline
\end{tabular}

Means followed for the same letters in the columns do not differ statistically by $F$ test at $5 \%$ probability $(p)$. Square root transformation performed for RL.

Table 5 - Percentage normal seedlings formation (\% NS), germination speed index (GSI) normal seedlings formation speed index (NSFSI) to seeds from matrix 4 of Psidium cauliflorum Landrum \& Sobral.

\begin{tabular}{lccc}
\hline Temperature & $\% \mathrm{NS}$ & GSI & NSFSI \\
\hline $25^{\circ} \mathrm{C}$ & $80.6 \mathrm{a}$ & $0.67 \mathrm{a}$ & $0.40 \mathrm{a}$ \\
$25-30^{\circ} \mathrm{C}$ & $70.5 \mathrm{a}$ & $0.21 \mathrm{~b}$ & $0.08 \mathrm{~b}$ \\
$30^{\circ} \mathrm{C}$ & $10.5 \mathrm{~b}$ & $0.72 \mathrm{a}$ & $0.43 \mathrm{a}$ \\
$\mathrm{F}$ & 161.88 & 16.35 & 1.69 \\
$\mathrm{p}$ & 0.00 & 0.00 & 0.00 \\
$\mathrm{CV} \%$ & 15.72 & 23.50 & 29.24 \\
\hline
\end{tabular}

Means followed for the same letters in the lines do not differ statistically by $F$ test at $5 \%$ probability $(p)$.

Temperature and photoperiod worked together for the variables: mean germination time (GT), seedling total length (STL) and $S$ seedling total mean length (STL 25).

Table 6 - Mean germination time (GT), seedlings total length (STL) and seedling total mean length (STL 25) of seeds from matrix 4 of Psidium cauliflorum Landrum \& Sobral.

\begin{tabular}{|c|c|c|c|c|c|c|}
\hline \multirow{3}{*}{$\begin{array}{l}\text { Causes of variation } \\
\text { Temperature }\end{array}$} & \multicolumn{6}{|c|}{ Photoperiod } \\
\hline & \multicolumn{2}{|c|}{ GT } & \multicolumn{2}{|c|}{ STL } & \multicolumn{2}{|c|}{ STL 25} \\
\hline & $12 \mathrm{~h}$ & $8 \mathrm{~h}$ & $12 \mathrm{~h}$ & $8 \mathrm{~h}$ & $12 \mathrm{~h}$ & $8 \mathrm{~h}$ \\
\hline $25^{\circ} \mathrm{C}$ & $38.2 \mathrm{aA}$ & $32.3 \mathrm{bA}$ & $4.3 \mathrm{aB}$ & $4.8 \mathrm{aA}$ & $0.17 \mathrm{aB}$ & $0.19 \mathrm{aA}$ \\
\hline $30^{\circ} \mathrm{C}$ & $27.0 \mathrm{bB}$ & $45.2 \mathrm{aA}$ & $2.9 \mathrm{bB}$ & $3.4 \mathrm{bA}$ & $0.11 \mathrm{bB}$ & $0.14 \mathrm{bA}$ \\
\hline $25-30^{\circ} \mathrm{C}$ & $32.5 \mathrm{abA}$ & $28.4 \mathrm{bA}$ & $4.2 \mathrm{aA}$ & $4.0 \mathrm{bA}$ & $0.17 \mathrm{aA}$ & $0.16 \mathrm{bA}$ \\
\hline $\mathrm{F}$ & \multicolumn{2}{|c|}{12.13} & \multicolumn{2}{|c|}{3.39} & \multicolumn{2}{|c|}{3.89} \\
\hline $\mathrm{p}$ & \multicolumn{2}{|c|}{0.00} & \multicolumn{2}{|c|}{0.04} & \multicolumn{2}{|c|}{0.04} \\
\hline CV\% & \multicolumn{2}{|c|}{16.01} & \multicolumn{2}{|c|}{7.81} & \multicolumn{2}{|c|}{7.81} \\
\hline
\end{tabular}

Means in the lines followed by uppercase letters and in the columns by lower case letters do not differ statistically at $5 \%$ probability by the $\mathrm{F}$ test.

The beginning of germination of seeds from matrix 4 differed between treatments (Kruskal-Wallis, chi-square $=15.5$ and $p$-value $=0.007$ ). The earliest germination occurred between 7 and 21 days, at $30^{\circ} \mathrm{C}$ and $12 \mathrm{~h}$ photoperiod. The latest germination occurred at the temperature of $30{ }^{\circ} \mathrm{C}$ and $8 \mathrm{~h}$ photoperiod, between 21 and 41 days. For the other treatments, germination started predominantly at 21 days. Normal seedling emergence started at 34 days, with no differences between treatments (Kruskal-Wallis, chi- square $=7.3$ and $p$-value $=0.2$ ). Maximum seedling emergence was earlier at temperatures of $25-30{ }^{\circ} \mathrm{C}$ (Kruskal-Wallis, chi-square $=11.6$ and $p$-value $=0.04$ ) occurring between 34 and 48 days, with predominance at 34 days.

Temperature and photoperiod preferences for the germination test in a controlled environment were not identical among the four matrices. In general, the best temperature and photoperiod conditions were alternating temperature of $25-30{ }^{\circ} \mathrm{C}$ and $8 \mathrm{~h}$ 
photoperiod, for matrices 1 and 3 ; alternating temperature of $25-30{ }^{\circ} \mathrm{C}$ and $12 \mathrm{~h}$ photoperiod, for matrix 2; and temperatures of $25^{\circ} \mathrm{C}$ and $25-30^{\circ} \mathrm{C}$ with 8h photoperiod for matrix 4.

According to Marcos Filho (2005), the response to light conditions may vary between individuals of the same species. Lima (2015) verified that seeds from different individuals of Senegalia bahiensis (Benth.) Seigler \& Ebinger have different demands for temperature and photoperiod, suggesting the use of this information to create homogeneous lots regarding germination traits.

According to Gualtieri \& Fanti (2015), the optimum germination temperature is expected to be within the temperature range recorded in the favorable period for seedling emergence, in the region of origin of the species under study. In this context, in the EPA of Lagoa de Pedra do Cavalo, place of natural occurrence of $P$. cauliflorum and where seed collection was conducted, the most favorable period for the germination and establishment of plants is between April and July. This period shows greater water availability, with minimum temperatures varying between $16-20{ }^{\circ} \mathrm{C}$ and maximum temperatures between $25-31^{\circ} \mathrm{C}$ (Instituto Nacional de Meteorologia,
2016). Therefore, the alternating temperature of $25-30{ }^{\circ} \mathrm{C}$, which provided comparatively better germination performance, is within the average temperature range for the place. The continuous temperature of $30{ }^{\circ} \mathrm{C}$, although within the maximum average temperature range of the place in the period favoring seedling emergence and establishment, compromises the germination of $P$. cauliflorum in a controlled environment.

Based on secondary data on temperature preference in germination tests for Brazilian native species, Brancalion et al. (2010) observed that alternating temperatures are most indicated in only $10 \%$ of the species. The majority of these species are early successional species, corroborating with the results obtained in this study. In the area where seed collection was carried out, $P$. cauliflorum occurs in the understory, in a shaded environment, suggesting that it is an early secondary species.

\section{Comparison between matrices}

Considering the characteristics presented in Table 7, it is observed that seeds from matrix 1 showed the best performance, followed by seeds from matrix 4.

Table 7 - Percentage of germination of normal seedlings (\% NSF), germination speed index (GSI) normal seedlings formation speed index (NSFSI), germination time (GT), time for normal seedlings formation (TNSF), shoot length (SL), root length $(R L)$ and total length ( $T L)$, shoot length (SL 25), root length (RL 25) and total length (TL 25) in relation to the number initial of seeds of the different matrix of Psidium cauliflorum Landrum \& Sobral.

\begin{tabular}{cccccccccccc}
\hline Matrix & \% NSF & GSI & NSFSI & GT & TNSF & SL & RL & TL & SL 25 & RL 25 & TL 25 \\
\hline 1 & $70.0 \mathrm{a}$ & $0.60 \mathrm{a}$ & $0.39 \mathrm{a}$ & $30.4 \mathrm{~b}$ & $44.6 \mathrm{~b}$ & $2.72 \mathrm{ab}$ & $2.43 \mathrm{a}$ & $5.15 \mathrm{a}$ & $0.11 \mathrm{ab}$ & $0.10 \mathrm{a}$ & $0.21 \mathrm{a}$ \\
2 & $58.0 \mathrm{a}$ & $0.39 \mathrm{~b}$ & $0.28 \mathrm{a}$ & $42.5 \mathrm{a}$ & $53.7 \mathrm{a}$ & $2.60 \mathrm{~b}$ & $1.26 \mathrm{~b}$ & $3.86 \mathrm{~b}$ & $0.10 \mathrm{~b}$ & $0.05 \mathrm{~b}$ & $0.16 \mathrm{~b}$ \\
3 & $31.0 \mathrm{~b}$ & $0.17 \mathrm{c}$ & $0.10 \mathrm{~b}$ & $47.6 \mathrm{a}$ & $54.7 \mathrm{a}$ & $2.54 \mathrm{~b}$ & $0.81 \mathrm{c}$ & $3.34 \mathrm{c}$ & $0.10 \mathrm{~b}$ & $0.03 \mathrm{c}$ & $0.13 \mathrm{c}$ \\
4 & $65.0 \mathrm{a}$ & $0.72 \mathrm{a}$ & $0.40 \mathrm{a}$ & $28.4 \mathrm{~b}$ & $41.6 \mathrm{~b}$ & $2.94 \mathrm{a}$ & $1.05 \mathrm{~b}$ & $4.00 \mathrm{~b}$ & $0.12 \mathrm{a}$ & $0.04 \mathrm{bc}$ & $0.16 \mathrm{~b}$ \\
$\mathrm{P}$ & 0.030 & 0.004 & 0.007 & 0.006 & 0.007 & 0.025 & 0.005 & 0.0048 & 0.022 & 0.005 & 0.005 \\
\hline
\end{tabular}

Means followed for the same letters in the columns do not differ statistically by Kruskal-Wallis test.

The beginning of germination differed between matrices (Kruskal-Wallis, chi-square $=12.74$ and $p$ value $=0.055$ ), being earlier in matrix 1 , at 20 days, followed by matrix 4 , at 21 days. Based on the germination behavior of seeds from the four $P$. cauliflorum matrices, five counts were performed, with the first count at 21 days, at 15-day intervals, ending at 77 days.
The number of seeds per 100 fruits (KruskalWallis, chi-square $=5.86$ and $p$-value $=0.12$ ), mean fruit diameter (Kruskal-Wallis, chi-square $=3.49$ and p-value $=0.32$ ) and seed width (Kruskal-Wallis, chisquare $=6.68$ and $p$-value $=0.08$ ) did not differ between matrices. Thousand seed weight was lower in matrix 3. Moreover, matrices 1 and 3 showed the smallest seed length (Table 8).

Table 8 - Length and weight of 1000 seeds of Psidium cauliflorum Landrum \& Sobral.

\begin{tabular}{ccc}
\hline Matrix & Length of the seed $(\mathrm{mm})$ & Weight of 1000 seeds $(\mathrm{g})$ \\
\hline 1 & $5.79 \mathrm{~b}$ & $65.17 \mathrm{a}$ \\
2 & $6.35 \mathrm{a}$ & $67.67 \mathrm{a}$ \\
3 & $5.48 \mathrm{~b}$ & $50.83 \mathrm{~b}$ \\
4 & $6.52 \mathrm{a}$ & $74.00 \mathrm{a}$ \\
$\mathrm{p}$ & 0.026 & 0.0003 \\
\hline
\end{tabular}

Means followed for the same letters in the columns do not differ statistically by Kruskal-Wallis test.

The difference between matrices regarding seed quality and preferences for light and temperature reinforces the need to consider these questions in the composition of homogeneous seed lots. Based on the results of this study, matrices 1 and 4 could compose the same seed lot, due to similarity in seed quality and 
preferences with respect to temperature and photoperiod. According to Lima (2015), for the composition of seed lots, it is necessary to analyze the differences between matrices to group them in terms of germination factors and common performances among them.

However, other issues need to be considered, such as the seed maturation stage. From one production cycle to another, the maturation period between matrices can differ. For example, seeds from matrix 3 had lower moisture content (1.24\%) than those from other matrices (12.4 to $23.4 \%$ ), suggesting that the former probably exceeded the physiological maturation point, which compromised its quality. According to Barbosa et al. (2015), after zygote formation, the seed moisture content is high (70-80\%), with slow dehydration during maturation, followed by intense desiccation. Studies on the physiological maturation stage are of fundamental importance to determine the optimum seed harvesting time, thus guaranteeing maximum yield and high physiological quality (Nogueira et al., 2013; Kaiser et al., 2016; Pires Neto et al., 2016).

Another question that must be considered is whether the matrices keep seed formation with the same level of quality from one production cycle to another. Pedroni et al. (2002), studying Copaifera langsdorffii Desf. observed that there are changes in the fruit production of this species during production cycles.

\section{Conclusions}

The recommended conditions for germination tests in $P$. cauliflorum seeds, in a controlled environment are alternating temperature of $25-30{ }^{\circ} \mathrm{C}\left(30{ }^{\circ} \mathrm{C}-16 \mathrm{~h} / 25^{\circ} \mathrm{C}-8 \mathrm{~h}\right), 8 \mathrm{~h}$ photoperiod, with the first count at 21 days and four subsequent counts at 15 days intervals.

\section{Acknowledgment}

The authors thank the Institute for Environmental and Water Resources (INEMA), BA.

\section{References}

Alvares CA, Stape JL, Sentelhas PC, Gonçalvez JLM, Sparovek, G (2013) Köppen's climate classification map for Brazil. Meteorologische Zeitschrift 22(6):711728. doi: 10.1127/0941-2948/2013/0507.

Barbosa MJ, Rodrigues MA, Barbério M, Araújo ACFB (2015) Colheita e Manejo de Sementes: Maturação de sementes de espécies florestais tropicais. In: PiñaRodrigues FCM, Figliolia MB, Silva A. Sementes Florestais Tropicais: da ecologia à produção. Londrina, PR: ABRATES, 477p.

Bernardes CO (2017) Diversidade genética, caracterização e atividade de óleos essenciais em Psidium spp. UFES. (Tese de doutorado em Genética e Melhoramento).
Biruel RP, Aguiar IB, Paula RC (2007) Germinação de sementes de pau-ferro submetidas a diferentes condições de armazenamento, escarificação química, temperatura e luz. Revista Brasileira de Sementes 29
(3):151-159.
doi:
$10.1590 / \mathrm{S} 0101-$

31222007000300018.

Borghetti F, Ferreira AG (2004) Interpretação de resultados de germinação. In: Ferreira AG, Borghetti F. Germinação do básico ao aplicado. (Org.). Porto Alegre: Artmed.

Brancalion PHS, Novembre ADLC, Rodrigues RR, Chamma HMCP (2008) Efeito da luz e de diferentes temperaturas na germinação de sementes de Heliocarpus popayanensis L. Revista Árvore 32(2):225-232. doi: 10.1590/S0100-67622008000200005.

Brancalion PHS, Novembre ADLC, Rodrigues RR (2010) Temperatura ótima de germinação de sementes de espécies arbóreas brasileiras. Revista Brasileira de Sementes 32(4):15-21. doi: 10.1590/S010131222010000400002 .

Brasil (2004) Decreto no 5.153. Diário oficial da República Federativa do Brasil. Poder executivo, Brasília, DF.

Brasil (2013) Instruções para análise de sementes de espécies florestais. Brasília: Ministério da Agricultura, Pecuária e Abastecimento 98 p.

Brasil (2003) Lei n. 10.711. Diário Oficial da República Federativa do Brasil. Poder executivo, Brasília, DF.

Brasil (2009) Regras para análise de sementes. Brasília: Ministério da Agricultura e Reforma Agrária 395 p.

Gualtieri SCJ, Fanti SC (2015) Germinação de Sementes: Ecofisiologia da germinação de sementes. In: Piña-Rodrigues FCM, Figliolia MB, Silva A. Sementes Florestais Tropicais: da ecologia à produção. Londrina, PR: ABRATES 477p.

Guedes RS, Alves EU, Gonçalves EP, Bruno RLA, Braga-Júnior JM. Medeiros MS (2009) Germinação de sementes de Cereus jamacaru DC. em diferentes substratos e temperaturas. Acta Scientiarum Biological Sciences 32(3):159-164. doi: 10.4025/actascibiolsci.v31i2.635.

Guedes MA, Mata MERMC, Duarte MEM, Farias PA (2011) Caracterização física de grãos de soja utilizando-se processamento digital de imagens. Revista Brasileira de Produtos Agroindustriais 13(3):279-294. doi: 10.15871/15178595/rbpa.v13n3p279-294.

Kaiser DK, Malavasi MM, Malavasi UC, Dranski JAL, Freitas LCN, Kosmann CR, Andrioli KK (2016) Physiological maturity of seeds and colorimetry of the fruits of Allophylus edulis [(A. St.-Hil., A. Juss. \& Cambess.) Hieron. ex Niederl.]. Journal of Seed Science 38(2):92-100. doi: 10.1590/2317$1545 v 38 n 2154590$. 
Landrum LR, Sobral M (2006) Psidium cauliflorum (Myrtaceae), a new species from Bahia, Brazil. SIDA, Contributions to Botany 22(2):927-929.

Lima TM (2015) Germinação e composição de lotes de sementes de Senegalia bahiensis (Benth.) Seigler \& Ebinger, UFRB (Dissertação de mestrado em Recursos Genéticos Vegetais).

Maguire JD (1962) Speed of germination-aid in selection and evaluation for seedlig emergence and vigor. Crop Science, Madison 2(1):176-177. doi:10.2135/cropsci1962.0011183X000200020033x.

Marcos Filho $J$ (2005) Fisiologia de sementes de plantas cultivadas. Piracicaba: FEALQ 495p.

Melo MGG, Mendonça MS, Patrícia NP, Mendes MAS (2011) Superação de dormência em sementes de três espécies de Parkia spp. Revista Brasileira de Sementes 33(3):533-542. doi: 10.1590/S010131222011000300016 .

Nogueira NW, Ribeiro MCC, Freitas RMO, Martins HVG, Leal CCP (2013) Maturação fisiológica e dormência em sementes de sabiá (Mimosa caesalpiniifolia Benth.). Bioscience Journal 29(4):876883.

Nogueira FCB, Gallão MI, Bezerra AME, Medeiros Filho S (2014) Efeito da temperatura e luz na germinação de sementes de Dalbergia cearensis Ducke. Ciên-

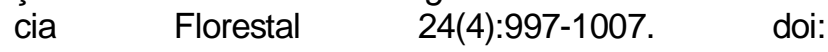
$10.5902 / 1980509816613$.

Pedroni F, Sanchez M, Santos FAM (2002) Fenologia da copaíba (Copaifera langsdorffii Desf. - Leguminosae, Caesalpinioideae) em uma floresta semidecídua no sudeste do Brasil. Revista Brasileira de Botânica 25(2):183-194. doi: 10.1590/S0100-
Pereira DS, Pereira, MS, Bezerra AME (2013) Efeito da Luz e da Temperatura na Germinação de Sementes de Cochlospermum vitifolium (Will.) Sprengel. Floresta e Ambiente 20(3):391-397. doi: 10.4322/floram.2013.026.

Pires Neto PAF, Pires VCM, Moraes CB, Oliveira LM, Portella ACF, Nakagawa J (2016) Physiological ripening of Anadenanthera colubrina (Vellozo) Brenan seeds. Journal of Seed Science 38(2):155-160. doi: 10.1590/2317-1545v38n2153112.

R Development Core Team. R: R version 3.1.3 (201503-09) -- "Smooth Sidewalk" Copyright (C) 2015 The R Foundation for Statistical Computing Platform: x86_64w64-mingw32/x64 (64-bit). Disponível em http://www.rproject.org (Acesso em 20 out 2016).

Silva A, Aguiar IB, Figliolia MB (2008) Germinação de sementes de Mimosa caesalpiniifolia Benth. (sansãodo-campo) sob diferentes condições de temperatura, luz e umidade. Revista do Instituto Florestal 20(2):139146.

Silva FJ, Hisatugo EY, Souza JP (2016) Efeito da luz na germinação e desenvolvimento inicial de plântulas de pinhão-manso (Jatropha curcas L.) de distintas procedências. Hoehnea 43(2):195-202. doi: 10.1590/2236-8906-80/2015.

Sobral M, Proença C, Souza M, Mazine F, Lucas E (2015) Myrtaceae. In: Lista de Espécies da Flora do Brasil. Jardim Botânico do Rio de Janeiro. Disponível em:

http://floradobrasil.jbri.gov.br/jabot/floradobrasi//FB108 59 (Acesso em 10 set 2016).

Souza, JS, Oliveira, L.P.; Conceição TA. (2018) Flora das APAS Lago Pedra do Cavalo e Joanes- Ipitanga. In: Mendonça AVR; Souza JS, Souza, MO, Santos JPA. (Orgs). Propagação de espécies nativas florestais nativas da Bahia. Cruz das Almas, BA. p. 428-446. 